\title{
STIMULATION OF ACTIVE SODIUM TRANSPORT BY THE ISOLATED TOAD BLADDER WITH ALDOSTERONE IN VITRO *
}

\author{
By JEAN CRABBÉ †
}

(From the Dcpartment of Medicine, Harvard Medical School, and the Massachusetts General Hospital, Boston, Mass.)

(Submitted for publication May 17, 1961 ; accepted August 8, 1961)

The tubular reabsorption of sodium in the mammalian kidney is stimulated after administration of aldosterone (1-3). The transport of sodium from the tubular lumen to the interstitial compartments, across the cells lining the renal tubule, represents an active process $(4,5)$, and one is therefore led to conclude that this process is influenced by aldosterone. However, the failure to observe a sodium retention confined to the treated side after injection of aldosterone into one renal artery of the normal dog (3) could cast doubt that aldosterone is the principle immediately responsible for renal sodium retention. The time lag of 1 to 2 hours regularly observed between intravenous administration of aldosterone and the first changes in sodium excretion by the kidney $(6-8)$ is likewise intriguing.

The isolated toad bladder was thought suitable for a more direct examination of the stimulation of sodium reabsorption by aldosterone. This preparation consists of a single layer of mucosal cells supported by thin connective tissue in which blood vessels and isolated bundles of smooth muscle are interspersed; a layer of serosal cells separates the bladder from the peritoneal cavity. This simple biological membrane is capable of moving sodium actively from its mucosal to its serosal border (9), a process that can be conveniently followed by the short-circuit technique of Ussing and Zerahn (10). These investigators have shown that, when an external potential is applied so as to

\footnotetext{
* Presented in part at the Annual Meeting of the American Society for Clinical Research, Atlantic City, N. J., May, 1960. This work was supported in part by grants from the John A. Hartford Foundation, Inc., the United States Public Health Service (H-2822) and the American Heart Association, Inc.

$\dagger$ Work done during tenure of a Research Fellowship of the Helen Hay Whitney Foundation, 1959-60. Present address: Department of Medicine, University Clinic St. Raphael, Louvain, Belgium.
}

nullify the spontaneous transmembrane potential, the current measured in the external circuit is the quantitative expression of active sodium transport.

Previous experiments have established that aldosterone is a physiological hormone for the toad, Bufo marinus, and that sodium transport by the toad urinary bladder is stimulated after injection of the steroid into the animal (11). For the present studies the membrane was exposed to aldosterone in vitro, and stimulation of active sodium transport ensued.

\section{MATERIAL AND METHODS}

All toads (Bufo marinus, male and female) were maintained half-immersed in distilled water for 3 to 5 days before sacrifice, except for half of those used in the first experiment. The animals were pithed and both half-bladders were mounted in rapid succession between Lucite chambers (20 $\mathrm{mm}$ ID) as described by Ussing and Zerahn (10), with the membrane bathing in 8 to 10 $\mathrm{ml}$ aerated frog Ringer solution $(\mathrm{Na}, 113.5 \mathrm{mEq}$ per $\mathrm{L}$; $\mathrm{K}, 1.88 \mathrm{mEq}$ per $\mathrm{L}: \mathrm{HCO}_{3}, 2.38 \mathrm{mEq}$ per L; Ca, 0.89 mmole per L; $\mathrm{Cl}, 114.9 \mathrm{mEq}$ per L; osmolality, $220 \mathrm{mOsm}$ per $\mathrm{kg}$ water; $\mathrm{pH}, 8.1$ at room temperature after equilibration with air). The serosal surface of one half-bladder was exposed to frog Ringer solution containing $d, l$ aldosterone in concentrations ranging from 10 to $180 \mu \mathrm{g}$ per $100 \mathrm{ml}$ : i.e., $1.4 \times 10^{-7} \mathrm{M}$ to $2.5 \times 10^{-6} \mathrm{M}$ biologically active $d$-aldosterone. Measurements of short-circuit current and of DC resistance were made at 15 - to 30-minute intervals for 3 to 4 hours. The DC resistance of the membrane was derived from the potential generated by imposing a current of $100 \mu \mathrm{a}$ across the short-circuited preparation. In some experiments $1 \mathrm{U}$ vasopressin (Pitressin: Parke, Davis) was added to the fluid bathing the serosal surface of the membrane after 180 to 210 minutes of incubation; short-circuit current was measured at 5-minute intervals during the following 20 to $30 \mathrm{~min}$ utes. In a series of 8 experiments, studies were performed on the short-circuited membrane, using $\mathrm{Na}^{24}$ and $\mathrm{Na}^{22}$ to measure the two unidirectional sodium fluxes simultaneously (9). Bladder tissue was analyzed for water, sodium, potassium, and chloride content as previ- 
ously described (11). Tissue glycogen concentration was determined by the anthrone method (12), after alkaline digestion of tissue samples stored frozen after incubation and weighing.

In some experiments $20 \mu \mathrm{g} d, l$-aldosterone 21-monoacetate (dissolved in $0.02 \mathrm{ml}$ ethanol diluted to $0.1 \mathrm{ml}$ with frog Ringer solution) was injected into the toads 24 and 4 hours before sacrifice. In another experimental series, $1 \mathrm{mg}$ deoxycorticosterone acetate (Schering sublingual tablets dissolved in $0.5 \mathrm{ml}$ frog Ringer solution) was injected into each animal daily for 5 days, with a last injection 4 hours before sacrifice.

\section{RESULTS}

1. In an initial series of experiments, paired half-bladders were obtained from 16 toads, 8 of which had been maintained in distilled water (water toads) and an equal number in saline (125 $\mathrm{mEq} \mathrm{Na}$ per L: saline toads) for 3 to 5 days. For each experiment one half-bladder served as a control, while the solution bathing the serosal surface of the corresponding half-bladder contained $2.8 \times 10^{-7} \mathrm{M} d$-aldosterone. Incubation was carried out for 4 hours. As seen in Figure 1 the mean short-circuit current across the membranes exposed to aldosterone started to increase above the control values after approximately $60 \mathrm{~min}-$ utes. The stimulation due to aldosterone be- came increasingly apparent with time. For the water toads during the last hour of incubation, the short-circuit current averaged $90.8 \pm 9.2 \mu \mathrm{a}$ per $3.14 \mathrm{~cm}^{2}$ as compared with a mean value of $37.7 \pm$ $3.5 \mu \mathrm{a}$ per $3.14 \mathrm{~cm}^{2}$ for the paired control halfbladders $(p<0.001)$. With the saline toads mean values were $42.6 \pm 8.5 \mu \mathrm{a}$ per $3.14 \mathrm{~cm}^{2}$ and $19.9 \pm 3.6 \mu \mathrm{a}$ per $3.14 \mathrm{~cm}^{2}$, respectively $(\mathrm{p}<$ $0.02)$. Relatively and absolutely, the stimulation by aldosterone of active sodium transport across the toad bladder was more marked in the case of the water toads. Therefore, water toads were used for all subsequent studies.

Experiments with paired bladder halves were carried out to minimize the variability of the aldosterone effect on active sodium transport by the isolated bladder from toad to toad. In addition, each membrane was used as its own control by expressing the short-circuit current during the third hour of incubation, when the effect of aldosterone was quite pronounced, relative to the shortcircuit current during the first hour of incubation, prior to a discernible hormonal effect. This form of presentation of the results seems justifiable because of the absence of a close correlation between sodium transport activity during the first hour of

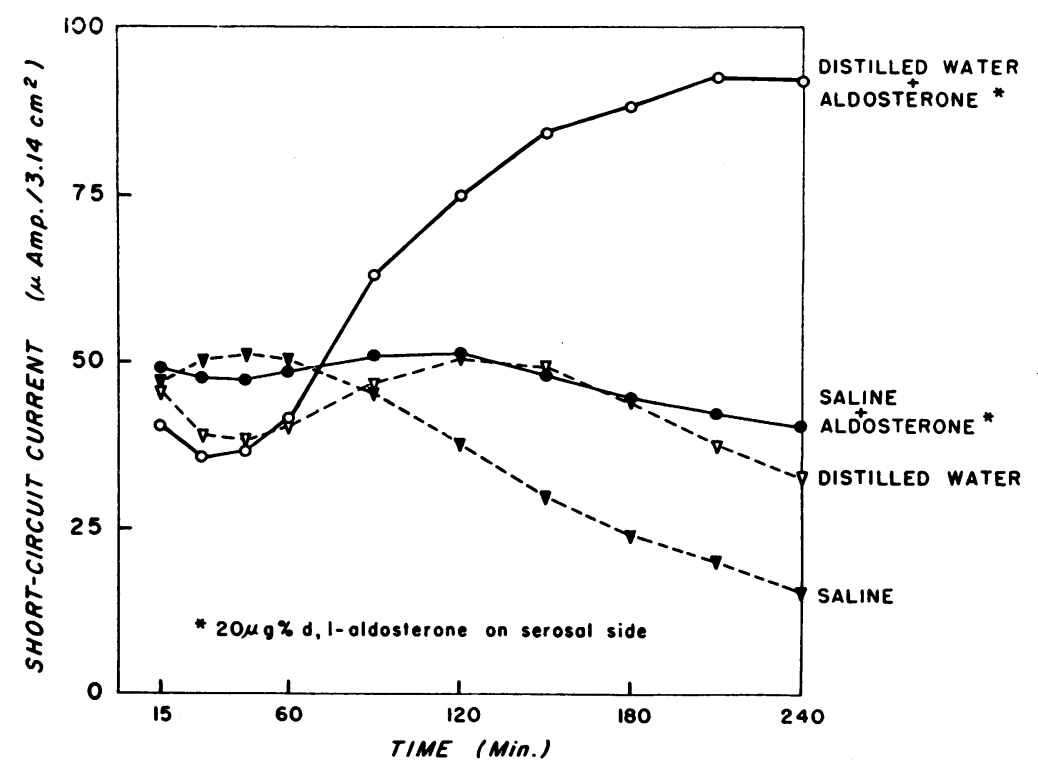

Fig. 1. Stimulation by aldosterone of active SOdium transport ACROSS THE TOAD BLADDER in vitro. Experiments performed on paired membranes. The serosal surface of one bladder half was exposed to aldosterone and the corresponding half served as control. Eight toads had been maintained in distilled water, eight in saline, prior to these incubations. 
TABLE I

Water, sodium, potassium, and chloride content of toad bladder tissue after stimulation of sodium transport by aldosterone in vitro *

\begin{tabular}{|c|c|c|c|c|}
\hline & Water & Sodium & Potassium & Chloride \\
\hline & $\begin{array}{l}\mu l / 100 \mathrm{mg} \\
\text { dry residue }\end{array}$ & & $\mu E q / g$ dry residue & \\
\hline \multirow{3}{*}{$\begin{array}{l}\text { Control tissue } \\
\text { Tissue exposed } \\
\text { to aldosterone }\end{array}$} & $381.6 \pm 10.2$ & $404.4 \pm 11.9$ & $299.8 \pm 12.3$ & $366.3 \pm 13.1$ \\
\hline & $367.7 \pm 14.3$ & $388.2 \pm 12.5$ & $291.0 \pm 11.6$ & $366.0 \pm 14.1$ \\
\hline & & & $\mu E q / g$ tissue water & \\
\hline Control tissue & & $107.4 \pm 4.9$ & $79.2 \pm 2.7$ & $96.7 \pm 3.7$ \\
\hline $\begin{array}{l}\text { Tissue exposed } \\
\text { to aldosterone }\end{array}$ & & $108.3 \pm 6.1$ & $80.5 \pm 4.1$ & $100.0 \pm 2.5$ \\
\hline
\end{tabular}

* Means \pm standard error of the means (SEM); each value represents the mean of 16 determinations; none of the differences is significant below the $40 \%$ level.

inculation and the spontaneous changes in sodium transport activity from the first to the third hour ( $\mathrm{R}=0.58$ for 98 untreated membranes).

2. After the incubation just described, bladder tissue was analyzed for water, sodium, potassium, and chloride contents. Values were grouped according to the experimental conditions in vitro (Table I). Although the half-bladders exposed to aldosterone transported more than twice as much sodium as their paired controls in the hour preceding the end of the incubation, no significant difference was detectable in tissue water and electrolyte composition.

3. The validity of the short-circuit current as a quantitative expression of net sodium transport during stimulation of the half-bladders by aldosterone in vitro was examined in another series of experiments. Bidirectional sodium flux determinations were carried out for five consecutive periods of 30 minutes across eight short-circuited toad bladders, the serosal surface of which was exposed to $2.8 \times 10^{-i} \mathrm{M} d$-aldosterone. From the results summarized in Table $I I$, it is apparent that the assumption is valid. The agreement between both types of measurement was as good during the entire period of aldosterone effect, from minute 60 on, as during the period of steady state (stable short-circuit current) extending through the last hour of incubation. The mean ratios given in the last column of Table II are an expression of this agreement for the individual 30-minute periods.

4. The stimulation of active sodium transport under the influence of aldosterone requires the expenditure of additional energy by the cells concerned. Leaf and Dempsey (13) have shown that increased glycolysis is associated with a stimulation of sodium transport after addition of vasopressin to the preparation under aerobic conditions. Glycogen was therefore measured in 15 pairs of pooled membranes, each pool containing 4 to 8 toad half-bladders. As seen in Table III there was a decrease in tissue glycogen concentration in eight of nine paired experiments for which sodium transport was known to have been stimulated by aldosterone. For Experiment 292, such a stimulation was merely assumed.

TABLE II

Agreement between net sodium transport and short-circuit current measurements in the isolated toad bladder exposed to aldosterone

\begin{tabular}{|c|c|c|c|c|}
\hline \multirow[b]{2}{*}{ Minutes } & \multirow{2}{*}{$\begin{array}{l}\text { Periods of } \\
\text { observation } \\
\text { of } 30 \mathrm{~min}\end{array}$} & \multicolumn{2}{|c|}{$\begin{array}{l}\text { Short-circuit current } \\
\left(\mu a / 3.14 \mathrm{~cm}^{2} \pm S E M\right)\end{array}$} & \multirow{2}{*}{$\frac{\text { Ratio derived }}{\begin{array}{c}\text { observed } \\
(\% 0 \pm \mathrm{SEM})\end{array}}$} \\
\hline & & Observed & $\begin{array}{l}\text { Derived from } \\
\text { sodium flux* }\end{array}$ & \\
\hline \multicolumn{5}{|l|}{ Total } \\
\hline 60 to 210 & 39 & $71.5 \pm 3.24$ & $71.3 \pm 5.48$ & $98.4 \pm 5.5$ \\
\hline $\begin{array}{l}\text { During steady state } \\
150 \text { to } 210\end{array}$ & 16 & $79.8 \pm 4.1$ & $80.6 \pm 8.7$ & $100.7 \pm 8.4$ \\
\hline
\end{tabular}

* A current of $1 \mu \mathrm{a}$ is generated by a net flux of $1.865 \times 10^{-2} \mu \mathrm{Eq}$ sodium per 30 minutes. 
TABLE III

Tissue glycogen content of the toad bladder after exposure to aldosterone in vitro *

\begin{tabular}{|c|c|c|}
\hline Pool no. & Control & +Aldosterone \\
\hline & \multicolumn{2}{|c|}{$\begin{array}{l}\text { A. Stimulation of sodium } \\
\text { transport by aldosterone }\end{array}$} \\
\hline $\begin{array}{l}190 \\
210 \\
230 \\
260 \\
240 \\
270 \\
112 \\
280 \\
290 \\
292\end{array}$ & $\begin{array}{l}589.7 \\
636.4 \\
890.0 \\
569.1 \\
562.3 \\
671.6 \\
500.0 \\
382.3 \\
471.3 \\
301.7\end{array}$ & $\begin{array}{l}580.2 \\
543.8 \\
633.1 \\
516.2 \\
610.8 \\
474.4 \\
252.3 \\
371.3 \\
408.5 \\
359.6\end{array}$ \\
\hline Mean & 557.4 & 475.0 \\
\hline \multicolumn{3}{|c|}{$\begin{array}{l}\text { Mean difference } \pm \mathrm{SE} \text { mean difference: } \\
\quad-82.4 \pm 36.4(\mathrm{p}<0.05)\end{array}$} \\
\hline & \multicolumn{2}{|c|}{$\begin{array}{l}\text { B. No stimulation of sodium } \\
\text { transport by aldosterone }\end{array}$} \\
\hline $\begin{array}{l}130 \\
140 \\
310 \\
330 \\
120\end{array}$ & $\begin{array}{l}488.3 \\
393.4 \\
297.6 \\
351.5 \\
221.0\end{array}$ & $\begin{array}{l}539.8 \\
419.9 \\
336.7 \\
344.7 \\
210.5\end{array}$ \\
\hline Mean & 350.4 & 370.3 \\
\hline
\end{tabular}

${ }^{*} \mu \mathrm{g} / 100 \mathrm{mg}$ wet tissue weight.

The action of aldosterone on the metabolism of the preparation is linked to the hormonal stimulation of active sodium transport. This is demonstrated in the second part of Table III by the absence of change in tissue glycogen concentration when sodium transport was not influenced by aldosterone- owing to concentrations of hormone insufficient to bring about a stimulation of sodium transport; to the presence of spirolactone that inhibited the effect of aldosterone on sodium transport (14); or to incubation of the membrane in a potassium-free medium in which no sodium transport takes place.

5. An attempt has been made to establish whether there is a quantitative relationship between the extent of the stimulation of active sodium transport by aldosterone and the concentration of the latter in the fluid bathing the serosal surface of the membrane. The results of this study are presented in Table IV. An adequate appraisal of such relationship is hampered by the variable activity of sodium transport across the toad bladder, as alı eady mentioned. No effect of aldosterone on sodium transport could be detected with a concentration of hormone of $1.4 \times$ $10^{-7} \mathrm{M}$ even when the values were compared with those obtained with the paired controls (eight experiments). On the other hand, in paired experiments a stimulation of sodium transport was noticeable with a concentration of $2.0 \times 10^{-7} \mathrm{M} d$-aldosterone. With larger concentrations there was generally a greater effect on sodium transport. The duration of the latent period, approximately 1 hour, was not influenced by these changes in hormone concentration.

6. The responsiveness of active sodium transport to aldosterone in vitro appears to be dependent upon the preconditioning of the toad. It has already been mentioned that the response of the isolated toad bladder to aldosterone in vitro was smaller with saline toads than with water toads. Plasma aldosterone concentration is lower in the saline than in water toads (11). When the

TABLE IV

Stimulation of active sodium transport by the isolated toad bladder as a function of the concentration of aldosterone

\begin{tabular}{|c|c|c|c|c|c|}
\hline \multirow{2}{*}{$\begin{array}{l}\text { No. of } \\
\text { expts. }\end{array}$} & & & \multicolumn{2}{|c|}{$\begin{array}{l}\text { Short-circuit current }\left(\mu \mathrm{a} / 3.14 \mathrm{~cm}^{2}\right) \\
\text { means } \pm \mathrm{SEM}\end{array}$} & \multirow{2}{*}{$\begin{array}{l}\text { Increase from } \\
\text { first to third hr } \\
(\% \text { 土propagated } \\
\text { SEM })\end{array}$} \\
\hline & & & First hour & Third hour & \\
\hline 98 & & Control & $56.26 \pm 2.36$ & $86.63 \pm 3.30$ & $167.2 \pm 5.7$ \\
\hline $\begin{array}{r}8 \\
15 \\
8 \\
52 \\
18 \\
12 \\
12 \\
12\end{array}$ & 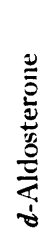 & $\begin{array}{l}1.4 \times 10^{-7} \mathrm{M} \\
2.0 \times 10^{-7} \mathrm{M} \\
2.4 \times 10^{-7} \mathrm{M} \\
2.8 \times 10^{-7} \mathrm{M} \\
4.0 \times 10^{-7} \mathrm{M} \\
5.6 \times 10^{-7} \mathrm{M} \\
10^{-6} \mathrm{M} \\
2.5 \times 10^{-6} \mathrm{M}\end{array}$ & 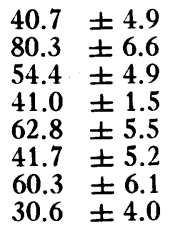 & $\begin{aligned} 52.0 & \pm 8.9 \\
115.0 & \pm 4.7 \\
124.5 & \pm 18.5 \\
91.0 & \pm 3.4 \\
142.8 & \pm 12.5 \\
115.4 & \pm 10.3 \\
134.1 & \pm 12.8 \\
101.1 & \pm 10.2\end{aligned}$ & $\begin{array}{l}121.3 \pm 20.8 \\
173.4 \pm 9.2 \\
215.0 \pm 17.4 \\
241.1 \pm 5.3 \\
247.4 \pm 12.3 \\
317.0 \pm 15.3 \\
242.3 \pm 13.9 \\
362.4 \pm 16.5\end{array}$ \\
\hline
\end{tabular}


TABLE V

Effect of aldosterone on active sodium transport by the isolated toad bladder; influence of the state of the process prior to experimental treatment

\begin{tabular}{|c|c|c|c|c|c|c|}
\hline \multirow[b]{2}{*}{ Preparation } & \multirow{2}{*}{$\begin{array}{l}\text { No. } \\
\text { paired } \\
\text { expts. }\end{array}$} & & \multicolumn{2}{|c|}{$\begin{array}{l}\text { Short-circuit current }\left(\mu \mathrm{\mu} / 3.14 \mathrm{~cm}^{2}\right) \\
\text { means } \pm \mathrm{SEM}\end{array}$} & \multirow{2}{*}{$\begin{array}{l}\text { Increase, first } \\
\text { to third hr } \\
(\% \pm \text { propagated } \\
\text { SEM })\end{array}$} & \multirow{2}{*}{$\begin{array}{l}\text { Signif. of } \\
\text { difference } \\
\text { between } \\
\text { control } \\
\text { and treated } \\
\text { paired } \\
\text { membranes }\end{array}$} \\
\hline & & & First hour & Third hour & & \\
\hline \multirow[t]{2}{*}{ Saline, 5 days } & \multirow[t]{2}{*}{8} & $\mathrm{C}^{*}$ & $49.3 \pm 6.2$ & $30.6 \pm 5.5$ & $54.4 \pm 21.9$ & \multirow{2}{*}{$\mathrm{p}>0.2$} \\
\hline & & $\mathrm{A}$ & $48.4 \pm 5.5$ & $48.1 \pm 8.3$ & $81.3 \pm 20.7$ & \\
\hline \multirow[t]{2}{*}{ Distilled water, 3 days } & \multirow[t]{2}{*}{8} & $\mathrm{C}$ & $42.0 \pm 2.4$ & $47.9 \pm 3.6$ & $113.7 \pm 9.4$ & \multirow{2}{*}{$\mathrm{p}<0.02$} \\
\hline & & $A$ & $39.7 \pm 3.3$ & $82.5 \pm 7.5$ & $220.6 \pm 12.3$ & \\
\hline \multirow{2}{*}{$\begin{array}{l}\text { Distilled water, } 3 \text { days: } \\
\text { inject. aldosterone } \\
24 \text { and } 4 \text { hours before } \\
\text { sacrifice }\end{array}$} & \multirow[t]{2}{*}{6} & $\mathrm{C}$ & $148.1 \pm 7.1$ & $172.3 \pm 10.3$ & $118.0 \pm 7.7$ & \multirow{2}{*}{$\mathrm{p}>0.7$} \\
\hline & & A & $136.0 \pm 13.3$ & $150.7 \pm 7.4$ & $121.8 \pm 10.9$ & \\
\hline \multirow{2}{*}{$\begin{array}{l}\text { Distilled water, } 5 \text { days: } \\
\text { daily injec. deoxy- } \\
\text { corticosterone }\end{array}$} & \multirow[t]{2}{*}{6} & $\mathrm{C}$ & $108.6 \pm 10.7$ & $100.0 \pm 6.2$ & $95.5 \pm 11.6$ & \multirow{2}{*}{$\mathrm{p}>0.5$} \\
\hline & & A & $119.4 \pm 8.9$ & $100.0 \pm 5.2$ & $90.8 \pm 9.1$ & \\
\hline
\end{tabular}

* $\mathrm{C}=$ control half-bladders. $\mathrm{A}=$ paired half-bladders; serosal surface was exposed to frog Ringer solution containing $2.8 \times 10^{-7} \mathrm{M} d$-aldosterone.

activity of sodium transport by the bladder was enhanced by injection of aldosterone into water toads the day prior to the incubations, an effect of aldosterone added to the membrane in vitro could no longer be demonstrated (Table V). The same observation was made after injection of deoxycorticosterone acetate daily for 5 days, which also results in a conspicuous increase of sodium transport by the preparation, as shown at the bottom of the first column of Table V.

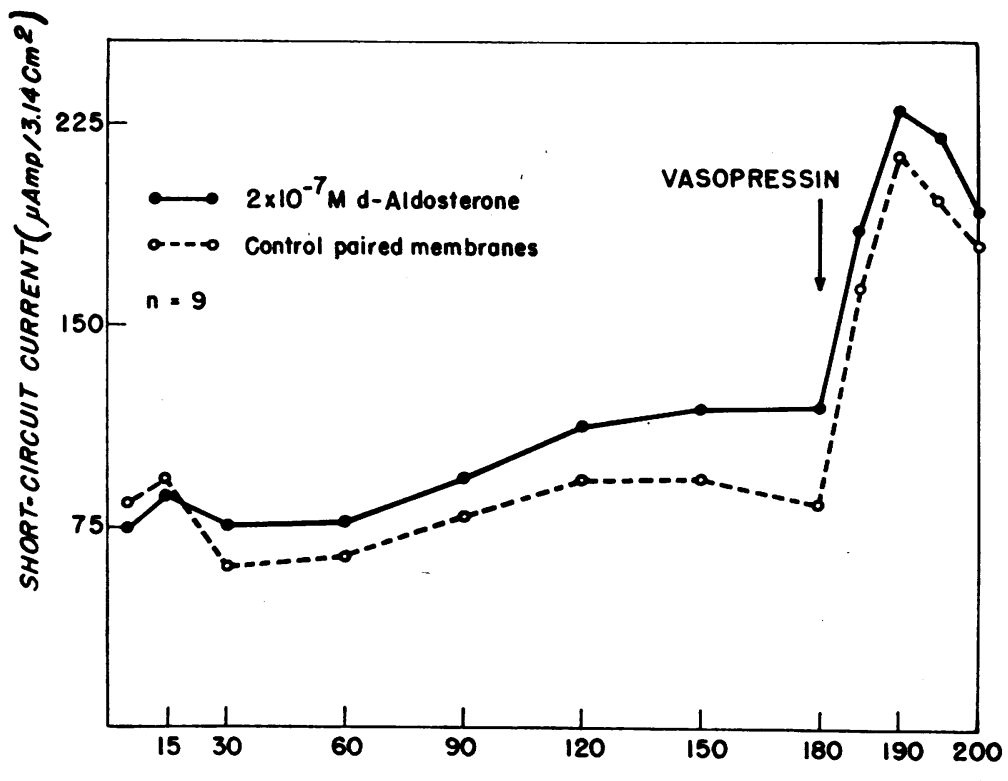

MINUTES

Fig. 2. ThIS SERIES OF NINE PAIRED EXPERIMENTS ILLUSTRATES THE ADDITIVE CHARACTER OF THE RESPONSE OF NET SODIUM TRANSPORT TO ALDOSTERONE AND TO VASOPRESSIN. 
7. Under the influence of aldosterone, the transmembrane potential increased almost proportionately to the hormonal effect on active sodium transport. Indeed, in 50 experiments the mean electric resistance of the untreated bladder half was $441 \pm 15.8 \mathrm{ohms}$ per $3.14 \mathrm{~cm}^{2}$ during the first hour of incubation, and $454 \pm 14.8$ ohms per 3.14 $\mathrm{cm}^{2}$ during the third hour. For the paired membranes exposed to aldosterone, the values averaged $414 \pm 14.5$ and $393 \pm 12.5 \mathrm{ohms}$ per $3.14 \mathrm{~cm}^{2}$, respectively.

8. Active sodium transport by membranes stimulated by aldosterone still exhibited the usual responsiveness to vasopressin. When aldosterone was used in nine paired experiments at a concentration of $2 \times 10^{-7} \mathrm{M}$, the short-circuit current during the third hour of incubation averaged 90.9 $\pm 5.9 \mu$ a per $3.14 \mathrm{~cm}^{2}$ for the control half-bladders, rising to a mean of $189.9 \mu$ a during the 20 -minute period that followed addition of vasopressin. For the paired half-bladders exposed to aldosterone, the mean values were $117.8 \pm 6.6$ and $211.1 \mu \mathrm{a}$ per $3.14 \mathrm{~cm}^{2}$, respectively (Figure 2). Thus the increase of short-circuit current was almost exactly the same for both groups of bladder halves. The additive character of the response of sodium transport to vasopressin and aldosterone has already been noticed after stimulation of sodium transport by injection of aldosterone into toads (11). When sodium transport was stimulated by injection of sodium-retaining steroid into water toads, a brisk response of sodium transport was still obtained after addition of vasopressin, even though these membranes no longer responded to aldosterone in vitro (Table V).

9. In 12 paired experiments deoxycorticoste-

TABLE VI

The influence of deoxycorticosterone on active sodium transport across the toad bladder in vitro

\begin{tabular}{|c|c|c|c|c|}
\hline \multirow{2}{*}{$\begin{array}{l}\text { No. } \\
\text { paired } \\
\text { expts. }\end{array}$} & & \multicolumn{2}{|c|}{$\begin{array}{c}\text { Short-circuit current } \\
\left(\mu \mathrm{a} / 3.14 \mathrm{~cm}^{2}\right) \\
\text { means } \pm \mathrm{SEM}\end{array}$} & \multirow{2}{*}{$\begin{array}{c}\text { Increase, } \\
\text { first to } \\
\text { third hr } \\
(\% \% \pm \text { propa- } \\
\text { gated SEM })\end{array}$} \\
\hline & & $\begin{array}{l}\text { First } \\
\text { hour }\end{array}$ & $\begin{array}{l}\text { Third } \\
\text { hour }\end{array}$ & \\
\hline \multirow{2}{*}{12} & $C^{*}$ & $35.4 \pm 3.4$ & $58.5 \pm 5.5$ & $168.2 \pm 13.4$ \\
\hline & DOC & $33.9 \pm 2.8$ & $51.3 \pm 4.4$ & $159.0 \pm 11.9$ \\
\hline
\end{tabular}

${ }^{*} \mathrm{C}=$ control half-bladders. $\mathrm{DOC}=$ paired half-bladders whose serosal surface was exposed to frog Ringer solution containing $2.0 \times 10^{-5}$ sterone in 6 experiments. rone was added to the solution bathing the serosal surface of the toad bladder in concentrations of 2.0 and $4.0 \times 10^{-5} \mathrm{M}$ in 0.1 per cent ethanol (vol/ vol). Although the latter are 200 times higher than effective concentrations of aldosterone, no effect on sodium transport could be observed despite an incubation lasting more than 4 hours (Table VI). The amounts of ethanol used to dissolve deoxycorticosterone do not modify the responsiveness of the preparation toward aldosterone.

\section{DISCUSSION}

These results demonstrate that active sodium transport can be stimulated by aldosterone in vitro. Concentrations of hormone less than seven times those found in the circulating blood of toads maintained in distilled water (11) were sufficient to elicit a significant elevation of the short-circuit current. The latter was shown to represent net sodium transport quantitatively. The equivalence between net sodium transport and shortcircuit current was discovered by Ussing and Zerahn with the isolated frog skin (10), and it applies to the toad bladder preparation under baseline conditions (9) as well as after addition of vasopressin (13).

Active sodium transport requires the expenditure of metabolic energy by the cells concerned. Leaf, Dempsey, Page and Anderson have shown that, in the toad bladder, glycolysis represents a source of energy used for sodium transport (13, 15). The observed increase in glycolysis resulting from the stimulation of sodium transport by aldosterone was therefore not surprising.

The mode and exact site of action of aldosterone on sodium transport are not elucidated. A stimulation of sodium transport by the hormone was not accompanied by measurable changes in bladder tissue water, sodium, potassium, or chloride concentrations. Such negative observations have been made previously in studies of the toad bladder (11) and of rat kidney slices (16). Changes in the activity of sodium transport across specialized cells, such as the mucosal cells of the toad bladder and the cells of the renal tubule, need not be reflected in gross alterations of their ionic composition. Measurements of the intracellular sodium pool concerned with sodium transport would un- 
doubtedly provide more meaningful information (17). On the other hand, in resting muscle cells, for instance, the active process is represented by an extrusion of sodium that balances the passive penetration of this ion across the cell membrane. After injection of aldosterone into mice, muscle sodium was actually decreased (18), presumably as the result of stimulation of the active process responsible for sodium extrusion.

Despite the variable pattern of sodium transport from one membrane to the other, as a rule an increased degree of stimulation of sodium transport resulted from incubation of the toad bladder with increasing concentrations of aldosterone. This was to be expected, since such a relationship forms the basis for measurement of aldosterone by bioassay (19-22). It is noteworthy that, as was the case with the toad bladder, the bioassay data failed to demonstrate a shortening of the latent period between administration of the steroid and the onset of sodium retention when larger amounts of aldosterone were used. This constitutes a strong argument that the latent period is not merely due to a slow build-up of the appropriate hormone concentration within the cell. A possibility is that aldosterone stimulates the synthesis of a substance involved in active sodium transport. This would explain the latent period and the dependency of the aldosterone action in ritro on the underlying activity of the sodium transport process as influenced by aldosterone secreted by or injected into the toad. Aldosterone in vitro had little effect on sodium transport when the adrenal secretion of aldosterone was low (saline toads). Immersion in distilled water, which results in a stimulation of the endogenous secretion of aldosterone, increased the responsiveness of the toad bladder to aldosterone in vitro. But, if sodium transport by the membrane was stimulated further, by a combination of a distilled water habitat and injection of a sodium-retaining steroid, aldosterone was devoid of measurable effect on sodium transport in vitro. Such observations confirm the studies made in vivo (11) and suggest that the hormone exerts its influence on a ratelimiting process.

The stimulation of sodium transport upon addition of vasopressin is added to that of aldosterone, and it is still demonstrable when aldosterone in vitro fails to influence sodium transport. Such independence suggests that the mechanism of action of both hormones on active sodium transport is different.

The complete lack of effect of deoxycorticosterone on sodium transport by the toad bladder in zitro merely confirms negative results obtained in the past with the isolated frog skin $(23,24)$. This ineffectiveness is intriguing because injection of the steroid into the toad brought about a large stimulation of sodium transport by the membrane, as shown in Table $\mathrm{V}$.

In the case of the toad urinary bladder, active sodium reabsorption, whether stimulated by aldosterone or not, is not linked to any measurable extent to potassium or hydrogen secretion, as indicated by the agreement between sodium flux and short-circuit current measurements. It is tempting to assume that, in the mammalian nephron also, aldosterone exerts its influence primarily upon active sodium transport. The increased secretion of potassium and hydrogen ions by the distal portion of the renal tubule after administration of aldosterone (6) could then be regarded as a mere consequence of the increased transtubular potential generated by the hormonal stimulation of sodium transport. The transmembrane potential of the toad bladder was higher when sodium transport was stimulated by aldosterone. In rats likewise, the distal transtubular potential is elevated during sodium depletion (25), a situation producing a hypersecretion of aldosterone by the adrenal cortex (6) .

\section{SLMMARY}

Active sodium transport by the isolated toad bladder was stimulated by aldosterone used in zitro at concentrations of 2.0 to $25 \times 10^{-7} \mathrm{M}$, in frog Ringer solution. This stimulation became apparent after a latent period of approximately 1 hour, and it was accompanied by an increase in the transmembrane potential. The effect of the steroid hormone on sodium transport was a function of its concentration as well as of the state of the animal prior to the experiments.

The stimulation of sodium transport under the influence of aldosterone was associated with an increased glycolysis. It did not modify the responsiveness of the preparation to vasopressin. 


\section{ACKNOWLEDGMENTS}

This work was done in the laboratory of Dr. Alexander Leaf, whom the author wishes to thank for his sustained interest and guidance. The aldosterone used for these studies was generously supplied by Dr. Robert Gaunt.

\section{REFERENCES}

1. Sala, G., and Luetscher, J. A., Jr. The effect of sodium-retaining corticoid, electrocortin, desoxycorticosterone, and cortisone on renal function and excretion of sodium and water in adrenalectomized rats. Endocrinology 1954, 55, 516.

2. Cole, D. F. Effect of aldosterone on renal excretion of intravenously administered saline. Endocrinology 1957, 60, 562.

3. Barger, A. C., Berlin, R. D., and Tulenko, J. F. Infusion of aldosterone, 9- $\alpha$-fluorohydrocortisone and antidiuretic hormone into the renal artery of nor$\mathrm{mal}$ and adrenalectomized unanesthetized dogs: Effect on electrolyte and water excretion. Endocrinology 1958, 62, 804.

4. Solomon, S. Transtubular potential differences of rat kidney. J. cell. comp. Physiol. 1957, 49, 351.

5. Giebisch, G. Electrical potential measurements on single nephrons of Necturus. J. cell. comp. Physiol. 1958, 51, 221.

6. Bartter, F. C. The role of aldosterone in normal homeostasis and in certain disease states. Metabolism 1956, 5, 369.

7. Thorn, G. W., Laidlaw, J. C., and Goldfien, A. Studies on the sodium-retaining effect of adernal cortical steroids. Ciba Found. Coll. Endocr. 1955, 8, 343.

8. Ross, E. J., Reddy, W. J., Rivera, A., and Thorn, G. W. Effects of intravenous infusions of dl-aldosterone acetate on sodium and potassium excretion in man. J. clin. Endocr. 1959, 19, 289.

9. Leaf, A., Anderson. J., and Page, L. B. Active sodium transport by the isolated toad bladder. J. gen. Physiol. 1958, 41, 657.

10. Ussing, H. H., and Zerahn, K. Active transport of sodium as the source of electric current in the short-circuited isolated frog skin. Acta physiol. scand. 1951, 23, 110.

11. Crabbé, J. Stimulation of active sodium transport across the isolated toad bladder after injection of aldosterone to the animal. Endocrinology. In press.
12. Roe, J. H. The determination of sugar in blood and spinal fluid with anthrone reagent. J. biol. Chem. 1955, 212, 335.

13. Leaf, A., and Dempsey, E. Some effects of mammalian neurohypophyseal hormones on metabolism and active transport of sodium by the isolated toad bladder. J. biol. Chem. 1960, 235, 2160.

14. Crabbé, J. Stimulation of active sodium transport across the isolated toad bladder by aldosterone in vitro. Clin. Res. 1960, 8, 227.

15. Leaf, A., Page, L. B., and Anderson, J. Respiration and active sodium transport of isolated toad bladder. J. biol. Chem. 1959, 234, 1625.

16. Crabbé, J., and Nichols, G., Jr. Effect of adrenalectomy, aldosterone and dehydration on electrolyte metabolism of rat renal cortex slices. Amer. J. Physiol. 1960, 199, 871.

17. Frazier, H. S., Dempsey, E. F., and Leaf, A. The initial step in active sodium transport by the toad bladder (abstract). J. clin. Invest. 1961, 40, 1039.

18. Woodbury, D. M., and Koch, A. Effects of aldosterone and desoxycorticosterone on tissue electrolytes. Proc. Soc. exp. Biol. (N. Y.) 1957, 94, 720.

19. Simpson, S. A., and Tait, J. F. A quantitative method for the bioassay of effect of adrenal cortical steroids on mineral metabolism. Endocrinology 1952, 50, 150.

20. Liddle, G. W., Cornfield, J., Casper, A. G. T., and Bartter, F. C. The physiological basis for a method of assaying aldosterone in extracts of human urine. J. clin. Invest. 1955, 34, 1410.

21. Johnson, B. B. Bioassay of adrenal cortical steroids on the basis of electrolyte excretion by rats: Effects of 11-desoxy and 11-oxy-steroids. Endocrinology 1954, 54, 196.

22. Singer, B., and Venning, E. H. Method of assay of a sodium-retaining factor in human urine. Endocrinology 1953, 52, 623.

23. Levinsky, N., cited by Sawyer, W. H. The hormonal control of water and salt-electrolyte metabolism with special reference to the Amphibia. Memoirs Soc. Endocr. (Cambridge Lniv. Press) 1956, 5, 44.

24. Borghghraef, R., cited by Ussing, H. H. The relation between active ion transport and bioelectric phenomena. Inst. Biofisica, Rio de Janeiro, 1955.

25. Rector, F. C., Jr. and Clapp, J. R. The mechanism of renal chloride reabsorption (abstract). J. clin. Invest. 1961, 40, 1075. 